\title{
Formation of valeological competence in non-medical students
}

\author{
Shevchenko A., Shtefan L.* \\ Ukrainian Engineering Pedagogics Academy, Kharkiv, Ukraine
}

Received: $17.10 .2021 \quad$ Accepted: 20.12 .2021

\begin{abstract}
Competence approach is generally accepted in modern education. Competence is the ability to perform a variety of practical tasks in life and professional activities at a sufficient professional level, which is due to cognitive abilities and skills, social interaction, motivation and will. There are lingual, informational (digital), communicational, cultural, ecological, valeological (health saving) and other competencies should be formed in the student, regardless of the profile of his education. In Ukrainian legislation, valeological competence is referred to the category of "civic and social competences". Valeological competence in educational standards given less importance than, for example, ecological competence. We have not found a clear definition of valeological competence. In our opinion, valeological competence is the ability to lead a healthy lifestyle, practice safe behavior and provide emergency care. For its formation in students of non-medical higher educational institutions we have proposed the initial academic discipline "Health Pedagogy". The study is theoretical, based on the analysis of scientific sources and regulations of Ukraine, including national educational standards. Preliminary data on the introduction of the author's program of the discipline "Pedagogy of Health" in the educational process of the Ukrainian Engineering Pedagogics Academy for students of "011 - Educational, Pedagogical Sciences" specialty "Bachelor" and "Master" educational levels are also taken into account. Requirements for valeological competence formation in non-medical students on accordance with the level of education, the proposed components of the curriculum and components of competence (cognitive, activity, motivational-value and personal) are formulated. The author's definition of valeological competence is supplemented with a list of its components subject to qualimetric assessment. The list of competencies, necessary for the valeological competence formation, as well as those competencies that are formed or improved simultaneously with the valeological competence during the study of valeological discipline "Health Pedagogy" by non-medical students.
\end{abstract}

Key words: competence approach to education, higher education standards in Ukraine, structure of valeological competence.

\section{Формування валеологічної компетентності у студентів немедичного профрілю навчання}

\author{
Шевченко О. С., Штефан Л. В. \\ Українська інженерно-педагогічна академія, Харків, Україна
}

\begin{abstract}
Анотація. Компетентнісний підхід $€$ загально прийнятим у сучасній освіті. Компетентністю $є$ спроможність виконувати варіативні практичні завдання у житті та професійній діяльності на достатньому професійному рівні, який обумовлений когнітивними здібностями та навичками, соціальною взаємодією, мотивацією та волею. Серед існуючих компетентностей, які мають бути сформованими у здобувача освіти, незалежно від профрілю його навчання, $є$ мовна, інфрормаційно-комунікаційна, загальнокультурна, екологічна, валеологічна (здоров'язбережувальна) та інші компетентності. В українському законодавстві валеологічна компетентність віднесена до категорії «громадянські та соціальні компетентності», в освітніх стандартах їй надається менше значення, чим, наприклад екологічній компетентності. Чітке визначення валеологічної компетентності нами не знайдене. На нашу думку, валеологічна компетентність - це спроможність вести здоровий спосіб життя, практикувати безпечну поведінку та надавати невідкладну допомогу. Для їі формування у студентів немедичних вищих навчальних закладів вищої освіти нами запропонована начальна дисципліна «Педагогіка здоров'я». Дослідження є теоретичним, грунтується на аналізі наукових джерел та нормативно-правових актів України, у тому числі національних освітніх стандартів. Враховані також попередні дані щодо впровадження
\end{abstract}

Corresponding Author: Shevchenko Alexander. Phone: +38 063069 9000. E-mail: al.shevchenko1976@gmail.com Ukrainian Engineering Pedagogics Academy, University str., 16, Kharkiv, Ukraine, 61003.

Відповідальний автор: Шевченко Олександр Сергійович. Тел. +38 063069 9000. E-mail: al.shevchenko1976@gmail.com Українська інженерно-педагогічна академія, вул. Університетська, 16, Харків, Україна, 61003 
авторської програми дисципліни «Педагогіка здоров'я» у навчальний процес Української інженернопедагогічної академії для студентів спеціальності «011 - Освітні, педагогічні науки» рівнів освіти «бакалавр» та «магістр». Сформульовані вимоги щодо фрормування валеологічної компетентності студентів немедичного профілю навчання відповідно до рівню освіти, запропонованих компонентів навчальної програми та складових компетентності (когнітивної, діяльнісної, мотиваційно-ціннісної та особистісної). Надане авторське визначення валеологічної компетентності доповнене списком її компонентів, які підлягають кваліметричній оцінці. Визначено перелік компетентностей, які є необхідною умовою для формування валеологічної компетентності, а також тих компетентностей, які формуються або вдосконалюються одночасно з валеологічної під час вивчення валеологічної дисципліни «Педагогіка здоров'я» студентами немедичного профілю навчання.

Ключові слова: компетентнісний підхід до навчання, стандарти вищої освіти України, структура валеологічної компетентності.

\title{
Формирование валеологической компетентности у студентов немедицинского профиля обучения
}

\author{
Шевченко А. С., Штефан Л. В.
}

Украинская инженерно-педагогическая академия, Харьков, Украина

\begin{abstract}
Аннотация. Компетентностный подход является общепринятым в современном образовании. Компетентностью называют способность выполнять вариативные практические задачи в жизни и профессиональной деятельности на достаточном профессиональном уровне, который обусловлен когнитивными способностями и навыками, социальным взаимодействием, мотивацией и волей. Среди существующих компетенций, которые должны быть сформированными у студента независимо от профиля его обучение, есть языковая, информационно-коммуникационная, общекультурная, экологическая, валеологическая (здоровьезберегающая) и другие компетентности. В украинском законодательстве валеологическая компетентность отнесена к категории «гражданские и социальные компетентности», в образовательных стандартах ей предается меньшее значение, чем, например, экологической компетентности. Четкое определение валеологического компетентности нами не найдено. По нашему мнению, валеологическая компетентность - это способность вести здоровый образ жизни, практиковать безопасное поведение и оказывать неотложную помощь. Для ее формирования у студентов немедицинских высших учебных заведений высшего образования нами предложена учебная дисциплина «Педагогика здоровья». Наше исследование является теоретическим (основывается на анализе научных источников и нормативно-правовых актов Украины, в том числе национальных образовательных стандартов), но нами также учтены предварительные данные по внедрению авторской программы дисциплины «Педагогика здоровья» в учебный процесс Украинской инженерно-педагогической академии для студентов специальности «011 - Образовательные, педагогические науки» уровней образования «бакалавр» и «магистр». Сформулированы требования по формированию валеологической компетентности студентов немедицинского профиля обучения в соответствии с уровнями образования, предложенными компонентами учебной программы и составляющих компетентности (когнитивной, деятельностной, мотивационноценностной и личностной). Авторское определение валеологической компетентности дополнено списком ее компонентов, подлежащих квалиметрической оценке. Определен перечень компетентностей, которые являются необходимым условием для формирования валеологической компетентности, а также список тех компетенций, которые формируются или совершенствуются одновременно с валеологической компетентностью при изучении валеологической дисциплины «Педагогика здоровья» студентами немедицинского профиля обучения.
\end{abstract}

Ключевые слова: компетентностный подход к обучению, стандарты высшего образования Украины, структура валеологической компетентности.

\section{Introduction}

Competence approach is generally accepted in modern education, both for primary education in schools and higher education, and for lifelong learning [1-3]. The competence approach is covered in the most detailed special pedagogical sources, and during adaptation to all existing specialties by concluding educational standards there can be mechanical repetitions of the made definitions which dissonant with the maintenance of these specialties $[4 ; 5]$. Competence is the ability to perform a variety of practical tasks in life and professional activities at a sufficient professional level, which is due to cognitive abilities and skills, social interaction, motivation and will [6]. 
According to the Law of Ukraine "On Education" [7], "competence - a dynamic combination of knowledge, skills, abilities, ways of thinking, views, values, other personal qualities that determine a person's ability to successfully socialize, conduct professional and/or further educational activities". According to the Law of Ukraine "On Higher Education" [8], "competence - the ability of a person to successfully socialize, learn, conduct professional activities, which arises on the basis of a dynamic combination of knowledge, skills, ways of thinking, views, values and other personal qualities". The educational process requires students in Ukraine to be fluent in the language of instruction, to be ready to learn throughout life, regardless of the profile of study to develop information and communication, cultural, competence, innovation, financial literacy, environmental competence, civic and social competences, "related to ideas democracy, justice, equality, human rights, prosperity and a healthy lifestyle, with an awareness of equal rights and opportunities". The Law also provides for "other competencies" defined by educational standards. For example, competencies in the field of natural sciences, engineering and technology, mathematical competence and others.

The relationship between competencies and educational standards has been studied in detail in European and North American scientific sources. Thus, R. Münch (2012) [9], states that because competencies are skills, and standards describe the level of achievement that is applied to knowledge and skills, these two concepts are often identified. At the same time, the definition of the content of competencies takes years. As there are no definitions of competencies that clearly reflect their content, their components are described in the context of standards [10]. In the context of health care, such components are often considered to be the absence of bad habits, protection from adverse environmental influences and sufficient physical activity. Instead of maintaining mental health, spiritual development is considered a component, instead of the need for a fully balanced diet - the rejection of fast food and GMOs. The disadvantage of identifying competence and educational standard is considered to be the subordination of competence to the standard. Also, the educational standards try to include those components of competence that are easy to model and measure [11; 12].

In different scientific sources and regulatory acts there are different definitions of competence, and the competences themselves belong to different classification groups. The Ukrainian educational standards [13] define the competencies that must be formed in students in accordance with the specialty and educational level - "bachelor" or "master". We did not find a clear and unambiguous definition of valeological competence in any normative act. In scientific sources, the definition and content of valeological (health saving) competence depends on the researcher's point of view, his education and teaching profile. Olle ten Cate (2017) believes [14] that valeological competence in medical students is formed in a mandatory manner in accordance with the curriculum and ethical attitudes. The formation of valeological competence in this case should be distinguished from diagnostic, treatment and prophylactic competencies aimed at patients [15]. It should also be borne in mind that educational standards on the main clinical specialties have not yet been approved by the Ministry of Education and Science of Ukraine. The question of the content of valeological competence and the success of its formation in non-medical students is considered insufficiently studied [16], which allows us to determine the purpose of our study.

Purpose of the study: to characterize the valeological competence of non-medical students of Ukrainian higher education institutions, to determine its components, conditions and normative principles of formation, the relationship with other competencies.

\section{Material and research methods}

The research materials were scientific publications (monographs, dissertations and articles) on pedagogy, orders of the Ministry of Education and Science of Ukraine, the Higher Attestation Commission of Ukraine, the Constitution of Ukraine, laws of Ukraine on science and education, 196 national standards of higher education (among which 34 belonged on education as the main scope, 14 - on security, guard, including the military, law enforcement, rescue and civil defense, 11 - on health care), World Health Organization's documents.

The study was conducted in accordance with the Passport of the specialty "13.00.01 - General Pedagogy and History of Pedagogy" [17], which regulates its directions and methodology, provides (among others) theoretical (fundamental and comparative) studies, study of domestic and foreign pedagogical achievements, patterns of pedagogical process, the structure of scientific knowledge, educational systems, 
conceptual apparatus, values and philosophy of education, world trends in education and pedagogical science, the unity and differences of pedagogical science and practice, worldviews of modern youth.

The study was conducted by the method of system analysis with large-scale detailing by E.P. Golubkov [18], which provides a sequence of actions of the researcher: problem statement $\rightarrow$ research $\rightarrow$ analysis $\rightarrow$ preliminary judgment $\rightarrow$ confirmation $\rightarrow$ final judgment $\rightarrow$ implementation of the decision. According to the chosen method and purpose of the study, the following actions are provided:

1. the task is to characterize the valeological competence of non-medical Ukrainian students of higher education institutions $\rightarrow$ to investigate the definition of valeological competence in regulations of Ukraine and some scientific publications $\rightarrow$ to analyze the causes of differences $\rightarrow$ to draw up a standardization plan in determining valeological competence and its place in classification $\rightarrow$ implementation of the decision;

2. the task is to determine the components of valeological competence $\rightarrow$ to investigate the definition of competence's components in the scientific literature $\rightarrow$ to analyze differences $\rightarrow$ to make a preliminary judgment about their significance and consequences $\rightarrow$ describe the started pedagogical experiment on formation and approbation of the curriculum of the corresponding academic discipline, which allows to form the valeological competence $\rightarrow$ identify valeological competence's components in accordance with the proposed curriculum of the academic discipline $\rightarrow$ to offer methods for assessing the formation of individual competence's components;

3. the task is to establish the relationship of valeological and other competencies that affect its formation or are formed together with it $\rightarrow$ to investigate the relationship of competencies $\rightarrow$ to analyze the consequences of lack of necessary additional competencies for human health $\rightarrow$ to determine the place of valeological competence among other competencies $\rightarrow$ test your own hypothesis about the importance of valeological competence for human health $\rightarrow$ determine the ratio of the achieved value of valeological competence with its place in the system of competencies of higher education standards of Ukraine $\rightarrow$ provide recommendations on methods of eliminating the identified contradictions.

\section{Results}

During the study of scientific sources and Ukrainian regulations it is established: regarding the saving and restoration of health/life in scientific sources named "valeological competence" and "health saving competence", in higher education standards and other regulations - "health saving competence".

Regarding the guidelines for health saving and life rescue, we have studied the educational standards approved by the Ministry of Education and Science of Ukraine. In the educational standards related to the pedagogical activity of higher education institutions (specialties 011,015, 016), among the special (professional) competencies are the ability to "use different types and forms of physical activity for active recreation and a healthy lifestyle", to organize work "in accordance with the requirements of environmental safety, safe lifestyle, occupational safety and hygiene", to organize the educational process in accordance with the special needs of some students. The educational standards of physical culture and sports (017) among the special (professional) competencies indicate the ability to "organize recreational physical activity of different groups of the population", "physical rehabilitation and adaptive sports", "strengthen human health through the use of motor activity, nutrition and other factors of a healthy lifestyle", "provide pre-medical care in case of emergencies". The educational standards of biology (091) require "biodiversity conservation, environmental protection, environmental management" and "the ability to analyze the results of the interaction of biological systems and the possibility of their use in various sectors of the economy, biotechnology, medicine and the environment". In the educational standards of ecology (101) among the general competencies is the ability to "use different types and forms of physical activity for active recreation and healthy living", and among the special (professional) named the ability "to identify technological environmental risks and inform the public about environmental safety"; among the program learning outcomes - the ability " to use different types and forms of physical activity to lead a healthy lifestyle". The last ability is indicated as the only one in relation to health in educational standards on chemistry (102), standards of exact sciences (104-123), among general competencies. Among the general competencies of the educational standard on chemistry (102) of the educational level "master" are also mentioned "the ability to act on the basis of ethical considerations (motives)" and "the ability to actively environment's protection". 
In educational standards related to fire safety (specialty 261), maintaining human health belongs to the category of special (professional) competencies. In educational standards related to civil defense (263), health saving is associated with the prevention of accidents and occupational diseases. In educational standards related to transport (271-275), valeological issues are not defined as a separate requirement, but only mentioned in the context of the ability to design vehicles with environmental safety requirements that are important for health. In most administrative, artistic, philosophical, economic, legal educational standards (for example, 281, 291, 292), in the educational standards of law enforcement and most military $(253-255,262)$ health saving is not mentioned at all. The only exception is the educational standard of state border guard (252), which provides for "the use of various types and forms of physical activity for active recreation and a healthy lifestyle."

The educational standards of veterinary medicine, hygiene and expertise $(211,212)$ among the general competencies indicate "the desire to environment protect", among the special (professional) - "the ability to analyze the safety of food and feed", "the ability to plan sanitary measures, develop procedures and monitor compliance with hygiene requirements... for the production of safe food ". In the educational standard of dentistry (221) among the general competencies content "the ability to act socially responsible" and the ability to "use different types and forms of physical activity for active recreation and healthy living", and among special (professional) competencies - numerous diagnostic, therapeutic, preventive, medical organizational, planned and emergency actions aimed at patients, as well as "the ability to assess the impact of the environment on the individual and population's health". The educational standard of nurses (223) among the general competencies contains "the ability to act on the basis of ethical considerations" and the ability to "use different types and forms of physical activity for active recreation and healthy living", and among special (professional) competencies - "the ability to recognize and interpret signs of health and its changes, illness or disability (assessment/ diagnosis), limitations of the possibility of full life and identify the problems of patients with various diseases and conditions", "ability to maintain their own health" while providing care to patients. Emphasis is also placed on the need for tolerant and reckless behavior, the need to provide the patient with a dignified attitude, privacy/intimacy and confidentiality. Similar emphasis is made in the educational standards of the specialties "Technologies of medical diagnostics and treatment" (224), "Physical therapy, ergotherapy" (227), "Social work" (231). In this case, the ability to use physical activity to lead a healthy lifestyle is grouped with the ability to preserve and multiply moral and cultural values.

The essence of health saving is the use of medical and hygienic methods, sports, environmental technologies, with emphasis on the direction in which the author is most aware. In the Ukrainian Engineering Pedagogics Academy from 2019/2020 academic year for students of "bachelor" and "master" educational levels of specialty "011 - Educational, pedagogical sciences" professors with medical and pedagogical education teach valeological discipline "Health pedagogy". Teaching is conducted according to the author's program with emphasis on diseases that, according to UN, WHO, Ministry of Health of Ukraine and the State Statistics Service of Ukraine statistics cause the highest number of diseases and deaths, and have controlled and conditionally controlled risk factors, i.e., subject to prophylactic's intervention. For the full formation of valeological competence, students must acquire knowledge about:

1) health;

2) diseases, their risk factors, symptoms, treatment and prophylactics;

3) practical skills (hygiene, self-examination, self-help, emergency care, others);

4) motivation to lead a healthy lifestyle and adhere to safe behavior patterns;

5) to improve ethics and skills of interaction on health issues with others, medical workers. the lists:

We offer the following list of information, actions, skills and personal qualities/abilities that correspond to

1) components of valeological competencies (cognitive, activity, motivational-value and personal);

2) topics of the curriculum of the discipline "Health Pedagogy" (table 1). 
Table 1. Components of valeological competence in accordance with the topics of the discipline "Health Pedagogy" and four pedagogical components

\begin{tabular}{|c|c|c|c|c|}
\hline \multirow{2}{*}{$\begin{array}{l}\text { Generalized topics of the } \\
\text { "Health pedagogy" } \\
\text { curriculum }\end{array}$} & \multicolumn{4}{|c|}{ Components of competence } \\
\hline & $\begin{array}{l}\text { Cognitive } \\
\text { (knowledge) }\end{array}$ & $\begin{array}{l}\text { Activity } \\
\text { (skill) }\end{array}$ & $\begin{array}{l}\text { Motivational and } \\
\text { value }\end{array}$ & $\begin{array}{l}\text { Personal } \\
\text { (required } \\
\text { qualities) }\end{array}$ \\
\hline 1 & 2 & 3 & 4 & 5 \\
\hline Personal hygiene & \multicolumn{2}{|c|}{$\begin{array}{l}\text { Washing, brushing teeth, care for } \\
\text { nose, eyes, intimate hygiene, clean } \\
\text { clothes (tools and techniques) }\end{array}$} & $\begin{array}{lr}\text { Feeling good, } \\
\text { perception by } \\
\text { others }\end{array}$ & Cleanliness \\
\hline $\begin{array}{l}\text { Household and medical } \\
\text { protection against } \\
\text { infectious diseases (anti- } \\
\text { epidemic regime and } \\
\text { vaccination) }\end{array}$ & $\begin{array}{l}\text { Current infectious } \\
\text { diseases, risks of } \\
\text { infection, } \\
\text { symptoms, } \\
\text { treatment, } \\
\text { prophylaxis }\end{array}$ & $\begin{array}{l}\text { Hygiene, screen } \\
\text { protection, } \\
\text { distance, time, } \\
\text { vaccination, } \\
\text { treatment }\end{array}$ & $\begin{array}{l}\text { Taking care of } \\
\text { yourself, others, } \\
\text { family }\end{array}$ & $\begin{array}{l}\text { Tolerance to } \\
\text { patients } \\
\text { according to the } \\
\text { risk of infection }\end{array}$ \\
\hline $\begin{array}{l}\text { Rational interaction with } \\
\text { medical workers and } \\
\text { pharmacists }\end{array}$ & $\begin{array}{l}\text { Possibilities of } \\
\text { self-medication, } \\
\text { physicians, } \\
\text { modern medicine, } \\
\text { laws of Ukraine }\end{array}$ & $\begin{array}{l}\text { Cooperation with } \\
\text { a physician, } \\
\text { pharmacist, } \\
\text { understanding of } \\
\text { the medical card }\end{array}$ & $\begin{array}{l}\text { Taking care of } \\
\text { yourself, interest } \\
\text { in the results of } \\
\text { the survey }\end{array}$ & $\begin{array}{l}\text { Trust } \\
\text { physicians, } \\
\text { sensitivity } \\
\text { patients }\end{array}$ \\
\hline $\begin{array}{l}\text { Skills of self- } \\
\text { examination, } \\
\text { determination of } \\
\text { restrictions and regime } \\
\text { according to the state of } \\
\text { one's own health }\end{array}$ & $\begin{array}{l}\text { Condition of skin } \\
\text { and appendages, } \\
\text { respiration, } \\
\text { heartbeat, } \\
\text { temperature, body } \\
\text { symmetry, vision, } \\
\text { hearing, smell, } \\
\text { things, } \\
\text { coordination, body } \\
\text { weight, emotions, } \\
\text { tumors }\end{array}$ & $\begin{array}{l}\text { Self-examination } \\
\text { in front of a } \\
\text { mirror, } \\
\text { measurement of } \\
\text { heart rate, } \\
\text { pressure, } \\
\text { temperature, } \\
\text { weight, glucose } \\
\text { level in patients } \\
\text { with diabetes, } \\
\text { palpation of the } \\
\text { breast, self- } \\
\text { diagnosis of } \\
\text { stroke }\end{array}$ & $\begin{array}{l}\text { Taking care of } \\
\text { yourself, } \\
\text { maintaining } \\
\text { health and life as } \\
\text { the greatest } \\
\text { values }\end{array}$ & Self-criticism \\
\hline $\begin{array}{l}\text { Ability to use medicines } \\
\text { from the home first aid } \\
\text { kit }\end{array}$ & \multicolumn{2}{|c|}{$\begin{array}{l}\text { Use of instructions to medicines and } \\
\text { devices, definition of expiration dates, } \\
\text { acquisition, application }\end{array}$} & $\begin{array}{l}\text { Willingness to } \\
\text { self-help and help } \\
\text { others }\end{array}$ & $\begin{array}{l}\text { Responsibility, } \\
\text { regulations, timely } \\
\text { call for } \\
\text { professional help } \\
\end{array}$ \\
\hline $\begin{array}{l}\text { The optimal mode of } \\
\text { work and rest, sleep }\end{array}$ & $\begin{array}{l}\text { Duration and } \\
\text { intensity of work, } \\
\text { which does not } \\
\text { exceed the } \\
\text { possibilities of } \\
\text { adaptation and } \\
\text { recovery through } \\
\text { rest and sleep }\end{array}$ & $\begin{array}{l}\text { Personal } \\
\text { protection against } \\
\text { industrial } \\
\text { hazards, burnout, } \\
\text { adequate rest } \\
\text { and sleep in } \\
\text { appropriate } \\
\text { conditions }\end{array}$ & $\begin{array}{l}\text { Feeling well; } \\
\text { positive mood } \\
\text { and activity; } \\
\text { adequate } \\
\text { reactions to } \\
\text { others who are } \\
\text { not affected by } \\
\text { fatigue }\end{array}$ & $\begin{array}{l}\text { Ability to plan } \\
\text { time and } \\
\text { conditions of work } \\
\text { and rest }\end{array}$ \\
\hline
\end{tabular}


ISSN 2307-9770. Engineering and Educational Technologies, 2021, 9 (4), 8-23. CC-BY @ KrNU, EETECS, Shevchenko A., Shtefan L., 2021

\begin{tabular}{|c|c|c|c|c|}
\hline 1 & 2 & 3 & 4 & 5 \\
\hline $\begin{array}{l}\text { Rational mode of } \\
\text { physical activity }\end{array}$ & $\begin{array}{l}\text { Training, gradual } \\
\text { increase } \\
\text { loadings, harmony } \\
\text { of physical and } \\
\text { intellectual } \\
\text { evolution }\end{array}$ & $\begin{array}{l}\text { Determining } \\
\text { one's own limit of } \\
\text { injuries and } \\
\text { failure to } \\
\text { compensate }\end{array}$ & $\begin{array}{l}\text { Effective physical } \\
\text { work and training } \\
\text { without injuries } \\
\text { and diseases, } \\
\text { weight } \\
\text { normalization }\end{array}$ & $\begin{array}{l}\text { Ability to plan the } \\
\text { mode of training, } \\
\text { physical work }\end{array}$ \\
\hline Rational nutrition & $\begin{array}{l}\text { Healthy and } \\
\text { special food, diets, } \\
\text { food safety, } \\
\text { bioadditives, } \\
\text { caloric content, } \\
\text { content of } \\
\text { components }\end{array}$ & $\begin{array}{l}\text { Evaluation and } \\
\text { review of the diet, } \\
\text { checking the } \\
\text { quality and shelf } \\
\text { life of food }\end{array}$ & $\begin{array}{l}\text { High life } \\
\text { expectancy and } \\
\text { quality, disease } \\
\text { prevention, } \\
\text { weight } \\
\text { normalization }\end{array}$ & $\begin{array}{l}\text { Self-criticism, the } \\
\text { ability to agree on } \\
\text { a joint diet in the } \\
\text { family }\end{array}$ \\
\hline $\begin{array}{ll}\text { Optimization } & \text { of } \\
\text { household ecology }\end{array}$ & $\begin{array}{l}\text { Domestic health } \\
\text { risks, constant and } \\
\text { extreme }\end{array}$ & $\begin{array}{l}\text { Adjustment of } \\
\text { lighting, } \\
\text { microclimate, } \\
\text { silence, fire } \\
\text { safety, hygiene of } \\
\text { houses }\end{array}$ & $\begin{array}{l}\text { Reducing the risk } \\
\text { of injuries, } \\
\text { diseases, } \\
\text { poisonings }\end{array}$ & $\begin{array}{l}\text { Ability to agree in } \\
\text { the family on safe } \\
\text { living conditions }\end{array}$ \\
\hline $\begin{array}{l}\text { Choosing a job } \\
\text { according to health } \\
\text { status }\end{array}$ & $\begin{array}{l}\text { Health restrictions, } \\
\text { occupational } \\
\text { diseases }\end{array}$ & $\begin{array}{l}\text { Prophylactic } \\
\text { examinations, } \\
\text { psychological } \\
\text { testing }\end{array}$ & $\begin{array}{l}\text { High life } \\
\text { expectancy and } \\
\text { quality, disease } \\
\text { prevention }\end{array}$ & $\begin{array}{l}\text { Self-criticism, } \\
\text { determining the } \\
\text { priority of health }\end{array}$ \\
\hline Safe traffic behavior & $\begin{array}{l}\text { Traffic rules, } \\
\text { statistics and } \\
\text { causes of road } \\
\text { accidents }\end{array}$ & $\begin{array}{l}\text { Observance of } \\
\text { traffic rules, } \\
\text { refusal to drive } \\
\text { vehicles tired, } \\
\text { after } \\
\text { psychoactive } \\
\text { substances use }\end{array}$ & $\begin{array}{l}\text { Minimization of } \\
\text { road accidents' } \\
\text { risk }\end{array}$ & $\begin{array}{l}\text { Responsibility, } \\
\text { normativeness, } \\
\text { care for others, } \\
\text { tolerance for } \\
\text { other people's } \\
\text { mistakes }\end{array}$ \\
\hline $\begin{array}{l}\text { Psychohygiene and } \\
\text { conflict resolution }\end{array}$ & $\begin{array}{l}\text { The norm of } \\
\text { mental health, } \\
\text { mental disorders, } \\
\text { the role of man in } \\
\text { conflicts, the } \\
\text { emotions of } \\
\text { conflict }\end{array}$ & $\begin{array}{l}\text { Preventive } \\
\text { examinations, } \\
\text { requests for } \\
\text { consultations, } \\
\text { self-diagnosis, } \\
\text { neuro-linguistic } \\
\text { techniques }\end{array}$ & $\begin{array}{l}\text { Mental health } \\
\text { saving, } \\
\text { psychological } \\
\text { balance } \\
\text { maintenance, } \\
\text { harmonious } \\
\text { relationships with } \\
\text { others, } \\
\text { minimizing of } \\
\text { conflicts' } \\
\text { consequences }\end{array}$ & $\begin{array}{l}\text { Self-criticism, } \\
\text { timely appeal for } \\
\text { professional help }\end{array}$ \\
\hline $\begin{array}{l}\text { Social interaction with } \\
\text { people with disabilities }\end{array}$ & $\begin{array}{l}\text { Inclusive } \\
\text { education, rights } \\
\text { and needs of } \\
\text { people with } \\
\text { disabilities }\end{array}$ & $\begin{array}{l}\text { Joint training with } \\
\text { the disabled }\end{array}$ & $\begin{array}{l}\text { Help and } \\
\text { tolerance are the } \\
\text { norms of modern } \\
\text { society }\end{array}$ & $\begin{array}{l}\text { Tolerance, } \\
\text { support }\end{array}$ \\
\hline
\end{tabular}


ISSN 2307-9770. Engineering and Educational Technologies, 2021, 9 (4), 8-23. CC-BY @ KrNU, EETECS, Shevchenko A., Shtefan L., 2021

\begin{tabular}{|c|c|c|c|c|}
\hline 1 & 2 & 3 & 4 & 5 \\
\hline $\begin{array}{l}\text { Protection against } \\
\text { violence, bullying }\end{array}$ & $\begin{array}{l}\text { Statistics of } \\
\text { bullying, domestic } \\
\text { violence, limits of } \\
\text { self-defense, types } \\
\text { of violence, victim } \\
\text { behavior }\end{array}$ & $\begin{array}{l}\text { Independent } \\
\text { cessation of } \\
\text { bullying and } \\
\text { domestic } \\
\text { violence, } \\
\text { knowledge of } \\
\text { their rights and } \\
\text { algorithm of } \\
\text { actions in case of } \\
\text { their violation }\end{array}$ & $\begin{array}{l}\text { Psychological } \\
\text { balance, } \\
\text { adequate } \\
\text { protection, } \\
\text { seeking help }\end{array}$ & $\begin{array}{l}\text { Self-worth, } \\
\text { intolerance of } \\
\text { bullying in one's } \\
\text { own presence }\end{array}$ \\
\hline $\begin{array}{l}\text { Emergency care, self- } \\
\text { help }\end{array}$ & $\begin{array}{l}\text { Vital functions of } \\
\text { the body, causes } \\
\text { and types of } \\
\text { death, shock, } \\
\text { coma, bleeding, } \\
\text { pain, risks of } \\
\text { emergencies in } \\
\text { asthma, diabetes, } \\
\text { predisposition to } \\
\text { allergies, the limit } \\
\text { of self-help and } \\
\text { seeking help }\end{array}$ & $\begin{array}{l}\text { Determining } \\
\text { one's own risks, } \\
\text { pre-hospital care } \\
\text { and self-help in } \\
\text { the presence of } \\
\text { bleeding, injuries, } \\
\text { burns, } \\
\text { poisonings, } \\
\text { allergies, bites, } \\
\text { cessation of } \\
\text { breathing and } \\
\text { heartbeat, safety } \\
\text { of the caregiver, } \\
\text { knowledge of } \\
\text { poisonous fungi, } \\
\text { insects, animals }\end{array}$ & $\begin{array}{l}\text { Preservation of } \\
\text { life and health, } \\
\text { own and other } \\
\text { victims }\end{array}$ & $\begin{array}{l}\text { Ability to survive, } \\
\text { care for yourself } \\
\text { and others }\end{array}$ \\
\hline $\begin{array}{l}\text { Absence of especially } \\
\text { dangerous bad habits } \\
\text { (tobacco smoking, } \\
\text { narcotic and toxic } \\
\text { psychoactive } \\
\text { substances use, alcohol } \\
\text { abuse) }\end{array}$ & $\begin{array}{l}\text { Statistics and } \\
\text { consequences of } \\
\text { tobacco, drugs } \\
\text { and toxic } \\
\text { substances, } \\
\text { alcohol use, } \\
\text { addiction } \\
\text { treatment, } \\
\text { rehabilitation }\end{array}$ & $\begin{array}{l}\text { Abstinence from } \\
\text { smoking, narcotic } \\
\text { and toxic } \\
\text { psychoactive } \\
\text { substances use, } \\
\text { moderate } \\
\text { consumption of } \\
\text { alcohol or } \\
\text { abstinence from } \\
\text { its use }\end{array}$ & $\begin{array}{l}\text { Preservation of } \\
\text { own health and } \\
\text { life, birth of } \\
\text { healthy children, } \\
\text { preservation of } \\
\text { social ties }\end{array}$ & $\begin{array}{l}\text { Taking care of } \\
\text { yourself and } \\
\text { others }\end{array}$ \\
\hline $\begin{array}{l}\text { Responsible sexual } \\
\text { behavior }\end{array}$ & $\begin{array}{l}\text { Anatomy and } \\
\text { physiology of the } \\
\text { female and male } \\
\text { reproductive } \\
\text { system, desirable } \\
\text { and undesirable } \\
\text { pregnancy, } \\
\text { pregnancy } \\
\text { planning } \\
\text { (preconception), } \\
\text { childbirth, } \\
\text { abortion, sexually } \\
\text { transmitted } \\
\text { diseases }\end{array}$ & $\begin{array}{l}\text { Harmonious } \\
\text { sexual } \\
\text { intercourse, } \\
\text { contraception } \\
\text { use, adequate } \\
\text { treatment of } \\
\text { sexual disorders } \\
\text { and sexually } \\
\text { transmitted } \\
\text { diseases }\end{array}$ & $\begin{array}{l}\text { Procreation } \\
\text { saving, refusal of } \\
\text { abortions without } \\
\text { medical } \\
\text { indications, } \\
\text { harmonious } \\
\text { family relations, } \\
\text { responsible } \\
\text { parenthood }\end{array}$ & $\begin{array}{l}\text { Loyalty } \\
\text { relationships, } \\
\text { responsibility, } \\
\text { self-control }\end{array}$ \\
\hline
\end{tabular}




\begin{tabular}{|c|c|c|c|c|}
\hline 1 & 2 & 3 & 4 & 5 \\
\hline Willingness to donate & $\begin{array}{l}\text { Blood and organ } \\
\text { donation, } \\
\text { transplantology, } \\
\text { laws of Ukraine } \\
\text { and other } \\
\text { countries of the } \\
\text { world, } \\
\text { technologies, } \\
\text { blood transmitted } \\
\text { diseases }\end{array}$ & $\begin{array}{l}\text { Blood donation, if } \\
\text { the state of } \\
\text { health allows, } \\
\text { consent to organ } \\
\text { and tissue } \\
\text { donation }\end{array}$ & $\begin{array}{l}\text { Help is the norm } \\
\text { of modern society }\end{array}$ & Caring for others \\
\hline
\end{tabular}

In accordance with the purpose and methodology of the study, valeological competence in our understanding is a ability to lead a healthy lifestyle, practice safe behavior and provide emergency care. A pedagogical experiment of teaching the discipline "Pedagogy of Health" for students from Ukraine and Germany on educational levels "bachelor" and "master" is conducted. The success of the formation of valeological competence is assessed by a qualimetric method, according to which the student's knowledge, skills and motivated actions are assessed in accordance with the experimentally assigned weight of the event. For example, within the topic of responsible sexual behavior, students are asked whether they use barrier contraception, provided they have sex. The affirmative answer should be detailed: is a condom always used? Did they refuse unprotected sex if there was no condom? Were there any emergencies (the condom remained in the vagina after intercourse, the condom broke)? Has the expiration date of the condom been checked before use? Did the condom fit the size of the penis? Was it bought well-known expensive condom brand, or the price factor was decisive? Were unwanted pregnancies and sexually transmitted diseases? Did they perform abortions at the request of a woman or a married couple, without medical indications? Each answer is assigned a weight. Compliance with a safe pattern of behavior adds points. It should be noted that for academic purposes, the assessment is given only for knowledge of barrier contraception and the ability to open the package of a condom and put it on a dildo. The student can get additional points only for changing the model of behavior to a safer one. Sex education classes for minors can be conducted only with the written consent of parents (guardians). It is desirable to teach this topic by a teacher with a medical education. $A$ separate publication will be devoted to the results of qualimetric evaluation.

Analysis of national educational standards for medical and non-medical specialties also allowed us to propose requirements for the formation of valeological competence for medical and non-medical education, which is presented in Table 2. We identified five levels of valeological competence's formation: remember and reproduce (1/5), understand (2/5), apply (3/5), analyze and interpret (4/5), create your own (5/5). Each subsequent level includes all previous ones.

Table 2. The required level of valeological competence formation for applicants for medical and nonmedical students in accordance with the educational level

\begin{tabular}{|c|c|c|c|c|c|}
\hline Requirements & $\begin{array}{l}\text { Remember and } \\
\text { replay }\end{array}$ & Understand & Apply & $\begin{array}{c}\text { Analyze and } \\
\text { interpret }\end{array}$ & Create \\
\hline \multicolumn{6}{|c|}{ Medical education } \\
\hline $\begin{array}{l}\text { Educational } \\
\text { level }\end{array}$ & & $\begin{array}{l}\text { Medical } \\
\text { university } \\
\text { graduate } \\
\text { student }\end{array}$ & $\begin{array}{l}\text { Nurse, } \\
\text { fel'dsher, intern }\end{array}$ & $\begin{array}{l}\text { Paramedic } \\
\text { (ambulance } \\
\text { physician), } \\
\text { primary care } \\
\text { specialist }\end{array}$ & $\begin{array}{l}\text { Secondary and } \\
\text { tertiary } \\
\text { specialist, } \\
\text { physician- } \\
\text { researcher }\end{array}$ \\
\hline \multicolumn{6}{|c|}{ Non-medical education } \\
\hline $\begin{array}{l}\text { Educational } \\
\text { level }\end{array}$ & & Bachelor & Master & & \\
\hline
\end{tabular}


We believe that in order to fulfill our proposed requirements for valeological competence's formation according to the educational level "bachelor" of non-medical education, online classes are enough, and for valeological competence's formation according for "master" level in non-medical students, practical classes in the classroom are necessary. First of all, to practice the methods of emergency medical care.

Also, the analysis of national educational standards allows us to define environmental competence as the one that has the greatest theoretical and ideological connection with valeological competence. The greatest connection with valeological competence from the number of competencies, the formation of which requires practical elaboration, has sports/physical training competence.

\section{Discussion}

Health saving technologies are a kind of pedagogical technologies. They are used in many specialized disciplines, which are called valeological [19]. The name "valeology" comes from Latin valeo - to be healthy, strong; and Greek lóyos - word, doctrine, science [21]. Among valeological disciplines in school and higher education, the most common are actually "Valeology", "Basics of Life Safety", "Basics of Medical Knowledge" and "Health Pedagogy" [22; 23]. The terms "health saving" and "valeological" are identical in meaning. As noted in the "Results" section, the main terminological discrepancy between scientific sources and regulations of Ukraine regarding valeological competence is the name of the competence itself: in scientific sources the name "valeological competence" and "health saving competence" are used simultaneously, in higher education standards and other normative (legal) acts of Ukraine define "competence of health saving". However, most of the differences are manifested in the understanding of what constitutes valeological competence. Unfortunately, not all authors, even textbooks of valeological disciplines, are able to identify the main components of health saving. Some textbooks even contain references to dubious methods of diagnosis and treatment, as well as openly unscientific methods, which are refuted by the methods of evidence-based medicine [23]. The most common emphasis is on environmental and sports technologies for maintaining and promoting health [24; 25]. Less common are accents on Eastern folk methods of diagnosis and treatment, secondary physiotherapy methods in the absence of a description of traditional European [26]. Authors of such methods often appeal to the WHO definition of "health", which is understood as " state of complete physical, mental and social well-being and not merely the absence of disease or infirmity" [27], distinguishing from the definition of "mental well-being" and proposing achieving spiritual practices and even religiosity. Such an approach violates the paradigm of secular education in Ukraine and is, in our opinion, unacceptable.

The random principle of including health issues in national educational standards is frankly surprising [13]. It is no coincidence that we have formed four groups of standards, which belong to: 1) the sphere of education as such (on pedagogy); 2) to safety and security (they carry an increased risk for the representatives of such professions and force these specialists to be in dangerous places, places where people may need urgent help); 3 ) to health care (for medical workers preservation and restoration of health is the purpose of action); 4) others. The standard of physical culture and sports (specialty 017) is the most detailed list of issues of preservation and restoration of health among non-medical educational standards. The lack of mention of health saving in management educational standards (281) does not cause such cognitive dissonance as the lack of such reference in the educational standards of the military and law enforcement $(252-255,262)$. If health is recognized as one of the highest values of Ukrainian society, and its protection is guaranteed by the state [28; 29, art. 3, 27, 49, 50], then law enforcement officers should have in the educational standard issues of emergency care, childbirth, ethical issues of use of force in terms of medical consequences of these actions; military personnel - issues of emergency assistance and ethical issues of the use of force against civilians during hostilities, against captured and wounded military adversaries. For representatives of professions that are needed in industrial production, it is appropriate to focus on possible occupational diseases, occupational health risks.

The identified combination of the ability to use physical activity to lead a healthy lifestyle with the ability to preserve and enhance moral and cultural values indicates the secondary role of valeological competence in the opinion of the compilers of national educational standards. In our opinion, the ability to lead a healthy lifestyle for non-medical students can indeed be a general competence, but mandatory for all without exception, educational standards, and without a combination of competencies on moral and cultural values. 
This combination is the reason for the authors of many textbooks of valeological disciplines in Ukraine to pay unjustifiably much attention to issues of national culture, history, folk traditions and religion.

It is important for our study to determine the relationship between competencies and educational standards. J. Glaesser (2019) [30] defines competence as a field of interest, not as knowledge, so he finds it useful to perceive all learning as the goal of acquiring competence, not knowledge. Education standards, according to the author, can be set taking into account the specific level of competence to be achieved, as well as the acquisition of knowledge, tuition costs, the number of teachers with a certain level of qualification, student satisfaction with learning. Education standards affect the further employment and funding of universities. To establish such relationships of competence formation, it is necessary to reliably measure what the proposed qualimetry of valeological competence. The author also points out the negative consequences of bringing all the necessary competencies under the existence of standards, among which in the first place is the reduction of teaching to training for successful passing of tests.

And yet in the practical dimension to consider the competencies that are formed in the educational process, it is advisable to consider in connection with educational standards. J. Fleischer et al. (2013) [31] notes that competencies are skills, and standards describe the level of achievement that can be applied to competencies. This approach will provide control over learning outcomes. Valeological competence should be separated from competencies related to spiritual values, folk traditions. The components of valeological competence defined by us allow to carry it to the general and obligatory, and for students of a medical profile of training - to special (professional) competences which are equally directed both to the medical worker, and to his patients.

In Introduction, we noted that the competencies that should be formed by the applicant in accordance with the specialty and educational level are specified in national educational standards, but in the list of standards of higher education in Ukraine we see only educational levels "bachelor" or "master". The Law of Ukraine "On Higher Education" [8] also specifies the educational level of "junior bachelor", which does not meet the standards of the Bologna Process and is added to the list of educational levels only in 2017. At the same time, Ukraine made the first real attempt to fulfill its obligations under the Bologna Process on the standardization of educational levels only in 2014. In the new law "On Higher Education" there was no educational level "junior bachelor", and the educational levels "specialist" and "junior specialist" were removed from the list [32]. Among the developed educational standards there are no ones that correspond to the educational level of "junior bachelor", which on the one hand gives us space for proposals, but on the other hand limits the search for requirements for the formation of competencies.

The lack of a definite list of components of health saving allowed us to offer our own list and our own definition of valeological competence. The issue of safe behavior, which we have singled out as the third component of valeological competence, deserves special attention. This action was carried out by us in connection with the European requirements for the description of competencies [33], which do not use negative wording. To practice safe behavior means "not to practice dangerous behavior". Of particular importance for a healthy lifestyle is the non-use of psychoactive substances (Table 1), which consists of the refusal to use them and a special (firm and conscious) attitude, according to which a person will never, under any circumstances, smoke or use drugs in recreational purposes. Human behavior in different typical situations, when there is a risk to health and life, is described by models, typical scenarios. The probability of their implementation is known through statistical studies. The number of people who abuse psychoactive substances is extremely high, and the consequences are tangible for personal and population health, add to the financial burden, which is projected for decades to come [34]. The safe model of behavior also includes situations of excessive risk to health and life during extreme sport and martial arts, conflicts with fights, work in high-risk occupations (with radiation, toxic chemicals and explosives, military service, work in law enforcement, fire safety and rescue guard, high-altitude and underwater work, etc.).

As already mentioned, the formation of the necessary competencies in the pedagogical process in Ukrainian higher education institutions is determined by national standards of higher education. Regarding the specialty "011 - Educational, pedagogical sciences" as of the beginning of October 2021 approved in Ukraine is only the standard of higher education of "master" educational level [35]. Therefore, a theoretical discussion in the scientific pedagogical environment of the content of the educational standard "011 - Educational, pedagogical sciences" (master) can be useful for legislators. In addition, this theoretical study helped us to 
distinguish in practical terms the materials of the academic discipline "Health Pedagogy" between the areas of education "bachelor" and "master", to develop and implement these issues in the educational process at the Ukrainian Engineering Pedagogics Academy [36] for bachelors of 011 specialty in 2019/2020-2020/2021 academic years [37]. The target competencies indicated by us in the materials of the curriculum should be clearly classified: their place among all competencies that are formed should be defined.

During the formation of special (professional, subject) competencies in accordance with the standard of specialty "011 - Educational, pedagogical sciences" students must form a critical understanding of the problems in the field of education at the boundaries of knowledge. This should include the ability to solve complex multidisciplinary and interdisciplinary tasks. In this case, the teaching of any discipline should be subject to the model of health. The necessary "ability to take into account the diversity and individual characteristics of students during the educational process" in the context of health saving is considered by us as an opportunity to assess the physical and psychological health of students, their special needs and limitations, to be tolerant of other students with special needs, to assist them in adapting to the initial process. Thus, Ukraine has adopted a strategy of mixed education of healthy students and students with special needs [38; 39]. The ability to solve interdisciplinary (research and/or innovative) problems of pedagogy is defined by the standard "011 - Educational, pedagogical sciences" as an integral competence. Ability to solve problems, tasks of research and/or innovation in the field of educational, pedagogical sciences.

In accordance with the standard of education, it is also necessary to acquire the ability to use modern information and communication (digital) technologies in educational and research activities, which we used to form valeological competence. Before the beginning of classes on "Health Pedagogy", we expect a level of mastery of information technology, sufficient for the full participation of students in the educational process, the established culture of communication in the information environment.

Some general competencies that must be formed in the master's degree in "011 - Educational, pedagogical sciences" also meet the conditions for the formation of valeological competence and effective training in the program of the academic discipline "Health Pedagogy". Thus, the ability to "learn", "search, process and analyze information from different sources", "abstract thinking, analysis and synthesis" are necessary for the levels of competence "remember and reproduce" and "understand" (Table 1). The ability to "identify, pose and solve problems", "apply knowledge in practical situations", to act adaptively (according to the situation), the ability to "interpersonal interaction" are necessary for the level of competence to "apply". The ability to "act socially responsibly and consciously" corresponds to the values on which valeological competence is based in matters of caring for the health of others, when a person agrees to donate his organs and tissues, for vaccination, stays at home if he has symptoms of infectious disease or provides emergency medical care to victims. Socially responsible behavior with concern for the health of others is not possible without values [40; 41], which appeals to the motivational and value component of competence and moral qualities of the person. The classification of the competence's components (cognitive, activity, motivationalvalue and personal) selected for the analysis of valeological competence is traditional, according to $\mathrm{V}$. $\mathrm{M}$. Vasyliuk (2021) [42].

Given the fact that in order to obtain a master's degree, persons who have obtained a bachelor's degree may be admitted, the formation of valeological competence must take place both during the bachelor's program and the master's program. But the requirements for the formation of competence should be different: for the educational level "bachelor" in our opinion it is enough to achieve the level of formation of valeological competence "understand", for the educational level "master" - the level of formation of valeological competence "apply".

The relationship of competencies required for health saving is not limited to the range of competencies defined by the educational standard. An obligatory component of valeological competence is environmental issues [43]. During the training of masters and bachelors in the specialty "011 - Educational, pedagogical sciences" on a theoretical level should discuss the ecology of houses in which students live and study, the management of household and industrial waste, the effects of air, soil and water pollution, the consequences of natural and man-made disasters, such as floods, droughts, forest fires, long-term environmental consequences of the Chernobyl accident [44; 45]. The study of environmental issues by non-medical students can take place at the departments of ecology or labor protection, if it is provided by the educational program. 
Thus, we have determined the composition of valeological competence, its connection with other competencies in the educational process of non-medical students, with national educational standards and state the implementation of the objectives of our study.

\section{Conclusions}

1. We have proposed the following definition of valeological competence: "the ability to lead a healthy lifestyle, practice safe behavior and provide emergency care". Its components you propose to consider: personal hygiene; household and medical prophylaxis against infectious diseases (anti-epidemic regime and vaccination); rational interaction with medical workers and pharmacists; skills of self-examination, determination of restrictions and regime in accordance with the state of one's own health; ability to use medicines the home first aid kit; optimal mode of work and rest, sleep; rational mode of physical activity; rational nutrition; optimization of household ecology; choosing a job according to health status; safe traffic behavior; psychohygiene and conflict resolution; social interaction with people with disabilities; protection against violence, bullying; emergency care, self-help; absence of especially dangerous bad habits (tobacco smoking, narcotic and toxic psychoactive substances use, alcohol abuse); responsible sexual behavior; willingness to donate. It is expedient to measure the success of the formation of valeological competence by qualimetric methods, which must be developed in accordance with the cognitive (knowledge), activity (skills), motivational-value and personal components of competence. The development of qualimetric criteria determines the main future perspective of the study. It is necessary to form the valeological competence of bachelors of non-medical profile at the level of "understand" (2/5), masters - at the level of "apply" (3/5).

2. Valeological competence, taking into account the value of health declared by the Ukrainian society and the state, should be included in all without exception national educational standards in the number of "special (professional, subject) competences" with definition of the necessary level of competence formation $(1-5 / 5)$ and emphasis on the training profile in accordance with the risk factors of the profession or its social role.

3. For the formation of valeological competence of students of non-medical higher education institutions, general competencies (cognitive, lingual, informational-communicational (digital), ability to learn, ability to act on ethical considerations), special competencies (human anatomy and chemistry at school level) are required. The formation of valeological competence occurs simultaneously with the formation of ecological competence and social competences of tolerant attitude to others, people with stigmatizing diseases, to victims of violence, people with disabilities. The competences of abstract and analytical thinking and the ability to act on the basis of ethical considerations are deepened.

\section{References}

1. Faber, L.W. (2021). Cultural competence education for health professionals: Summary of a cochrane review. Explore, 17(4), 383-384. DOI: https://doi.org/10.1016/j.explore.2021.04.011

2. Zhao, Y., Llorente, A. M. P., Gómez, M. C. S. (2021). Digital competence in higher education research: A systematic literature review. Computers \& Education, 168, 104212. DOI: https://doi.org/10.1016/j.compedu.2021.104212.

3. Garzón-Artacho, E., Sola-Martínez, T., Romero-Rodríguez, J.-M., Gómez-García, G. (2021). Teachers' perceptions of digital competence at the lifelong learning stage. Heliyon, 7(7), e07513. DOI: https://doi.org/10.1016/j.heliyon.2021.e07513.

4. Romijn, B. R., Slot, P. L., Leseman, P. P. M. (2021). Increasing teachers' intercultural competences in teacher preparation programs and through professional development: A review. Teaching and Teacher Education, 98, 103236. DOI: https://doi.org/10.1016/j.tate.2020.103236

5. Fauth, B., Decristan, J., Decker, A.-T., Büttner, G., Hardy, I., Klieme, E., Kunter, M. (2019). The effects of teacher competence on student outcomes in elementary science education: The mediating role of teaching quality. Teaching and Teacher Education, 86, 102882. DOI: https://doi.org/10.1016/j.tate.2019.102882

6. Glaesser, J. (2019). Competence in educational theory and practice: a critical discussion. Oxford Review of Education, 45(1), 70-85. DOI: https://doi.org/10.1080/03054985.2018.1493987

7. Law of Ukraine 2145-VIII "On Education", adopted on 05 Sep 2017, with changes and additions from 18 Dec 2018-07 Sep 2021, valid. Information of the Verkhovna Rada (VVR), 2017, No.38-39, Art. 380. URL: https://zakon.rada.gov.ua/laws/show/214519\#Text (accessed 20.09.2021). [Ukrainian]

8. Law of Ukraine 1556-VII "On higher education", adopted on 01 Jul 2014, with changes and additions from 28 Dec 2014-07 Sep 2021, valid. Information of the Verkhovna Rada (VVR), 2014, No.37-38, Art. $2004 . \quad$ URL: https://zakon.rada.gov.ua/laws/show/1556-18\#Text (accessed 20.09.2021). [Ukrainian] 
9. Münch, R. (2012). Mit dem PISA-Express in die globale Wissensgesellschaft. In M. Pfadenhauer \& A. M. Kunz (Eds.). Kompetenzen in der Kompetenzerfassung. Ansätze und Auswirkungen der Vermessung von Bildung (pp. 121-132). Weinheim: Beltz Juventa.

10. (2011).Teaching: the Reflective Profession. Incorporating the Northern Ireland Teacher Competences. 54. URL: https://is.gd/aupsVx (accessed 20.09.2021).

11. McKinnon, T., Smedley, C.T. \& Evert, J. (2017). Service learning as a framework for competency-based local/global health education. Annals of Global Health, 82(6), p. 1034-1042. DOI: http://doi.org/10.1016/j.aogh.2016.11.004

12. Paquette, G., Marino, O., Bejaoui, R. (2021). A new competency ontology for learning environments personalization. Smart Learn. Environ, 8, 16. DOl: https://doi.org/10.1186/s40561-021-00160-z

13. Approved standards of higher education. Ministry of Education and Science of Ukraine, official website. URL: https://is.gd/y2c7EW (accessed 20.09.2021). [Ukrainian]

14. Olle ten Cate (2017). Competency-Based Postgraduate Medical Education: Past, Present and Future. GMS J Med Educ, 34(5), Doc69. DOI: https://doi.org/10.3205/zma001146

15. Prediger, S., Schick, K., Fincke, F., Fürstenberg, S., Oubaid, V., Kadmon, M., Berberat, P. O., Harendza, S. (2020). Validation of a competence-based assessment of medical students' performance in the physician's role. BMC Med Educ, 20, 6. DOI: https://doi.org/10.1186/s12909-019-1919-x

16. Maksymchuk, B., Matviichuk, T., Solovyov, V., Davydenko, H., Soichuk, R., Khurtenko, O., Groshovenko, O., Stepanchenko, N., Andriychuk, Y., Grygorenko, T., Duka, T., Pidlypniak, I., Gurevych, R., Kuzmenko, V., Maksymchuk, I. (2020). Developing Healthcare Competency in Future Teachers. Revista Romaneasca Pentru Educatie Multidimensionala, 12(3), 24-43. DOI: https://doi.org/10.18662/rrem/12.3/307

17. Passport of specialty 13.00 .01 - general pedagogy and history of pedagogy. Resolution of the Presidium of the High Attestation Commission of Ukraine No. 066-06/8 on 14 Sep 2006 "On approval of the list of passports in the field of pedagogical sciences" (valid on 07 Oct 2021). URL: https://zakon.rada.gov.ua/rada/show/v06-0330-06\#Text (accessed 20.09.2021). [Ukrainian]

18. Golubkov's method. System analysis laboratory. URL: http://systems-analysis.ru/golubkov_method.html (accessed 20.09.2021). [Russian]

19. Rybalko, L. M. (Ed.), Osadtsa, V. M. (Ed.) (2019). Health saving technologies in the educational environment. Collective monograph. Ternopil, 400. ISBN 978-617-7793-05-1. URL: https://is.gd/8CTJmG (accessed 20.09.2021).

20. Brekhman, I. I. (1990). Valeology - the science on health. Moscow: Physical Culture and Sports, 208. ISBN 5-278-00214X. [Russian].

21. Yeresko, O. V. (2018). Education of valeological values of adolescents in the process of educational and extracurricular activities. Diss. cand. ped. sciences spec. 13.00.07 "Theory and a technique of education" (011 - Educational, pedagogical sciences). National University of Life and Environmental Sciences of Ukraine, Volodymyr Dahl East Ukrainian National University, Kyiv. 172 p. URL: https://snu.edu.ua/wp-content/uploads/2018/11/Eresko-O.V.-dysertatsiya.pdf (accessed 20.09.2021). [Ukrainian].

22. Sulima, A. S. (2019). Methods of teaching the basics of health, valeology and conducting educational work on the formation of motivation for a healthy lifestyle: lecture texts: a textbook for students of higher education bachelor's degree in secondary education. Specialty 014 - Secondary education (Human health). Vinnytsia. 182 p. URL: https://vspu.edu.ua/faculty/sport/doc/metod14.pdf (accessed 20.09.2021). [Ukrainian]

23. Marik, P.E. (2015). Evidence-Based Critical Care. Springer International Publishing, 835. URL: https://www.springer.com/gp/book/9783319110196 (accessed 20.09.2021).

24. Halaidiuk, M., Maksymchuk, B., Khurtenko, O., Zuma, I., Korytko, Z., Andrieieva, R., Strykalenko, Y., Zhosan, I., Syvokhop, Y., Shkola, O., Fomenko, O., Maksymchuk, I. (2018). Teaching approaches in extracurricular physical activities for 12-14-year-old pupils under environmentally unfavourable conditions. Journal of Physical Education and Sport, 18 (4), 2284-2291. DOI: https://doi.org/10.7752/jpes.2018.04344

25. Paquette, G., Marino, O., Bejaoui, R. (2021). A new competency ontology for learning environments personalization. Smart Learn. Environ, 8, 16. DOI: https://doi.org/10.1186/s40561-021-00160-z

26. Mikisek, I. (2015). Evidence Based Management. Gabler Verlag, 131. ISBN 978-3-658-09774-5. URL: https://is.gd/vpLrdK (accessed 20.09.2021).

27. Constitution of the World Health Organization. Adopted on 19 June-22 July 1946, entered into force on 7 April 1948, with changes and additions 3 February 1977-15 September 2005. New York, Geneva. 20 p. URL: https://www.who.int/governance/eb/who_constitution_en.pdf (accessed 20.09.2021).

28. Boychuk, Yu. D. (Ed.) (2017). General theory of health and healthcare: a collective monograph. Publisher Rozhko S. G., Kharkiv, Uktaine, 488. ISBN 978-966-97499-4-9.

29. Constitution of Ukraine. Adopted on 28 Jun 1996, legislative act No. 254k/96-VR, with changes and additions from 08 Dec 2004-02 Dec 2019, is valid. Information of the Verkhovna Rada of Ukraine (IVR), 1996, No. 30, Art. 141. URL: https://zakon.rada.gov.ua/laws/show/254k/96-вp (accessed 20.09.2021). [Ukrainian]

30. Glaesser, J. (2019). Competence in educational theory and practice: a critical discussion. Oxford Review of Education, 45(1), 70-85. DOI: https://doi.org/10.1080/03054985.2018.1493987

31. Fleischer, J., Koeppen, K., Kenk, M., Klieme, E., Leutner, D. (2013). Kompetenzmodellierung: Struktur, Konzepte und Forschungszugänge des DFG-Schwerpunktprogramms [Competency modeling: structure, concepts and research approaches of the DFG priority program]. Z Erziehungswiss, 16, 5-22. DOI: https://doi.org/10.1007/s11618-013-0379-z [German].

32. Shevchenko, V. V. (2019). The reform of the higher education of Ukraine in the conditions of the military-political crisis. International Journal of Educational Development, 65, 237-253. DOI: https://doi.org/10.1016/j.jjedudev.2018.08.009 
33. European Commission (2013). ESCO: European Classification of Skills, Competences, Qualifications and Occupations. [Internet], URL: https://ec.europa.eu/esco/portal/home (accessed 20.09.2021).

34. WHO Framework Convention on Tobacco Control. URL: https://fctc.who.int/ (accessed 20.09.2021).

35. Standard of higher education of Ukraine, specialty 011 Educational, pedagogical sciences (master's degree), approved by the Ministry of Education and Science of Ukraine order No. 520 on 11 May 2021 (valid on 07 Oct 2021). Approved standards of higher education. Ministry of Education and Science of Ukraine, official website. URL: https://is.gd/y2c7EW (accessed 20.09.2021). [Ukrainian]

36. Ukrainian Engineering Pedagogics Academy. HEl review. URL: http://www.uipa.edu.ua/en/ (accessed 20.09.2021).

37. Shtefan, L. V., Shevchenko, A. S. (2019). Materials of academic discipline "Health Pedagogy": lectures, guidelines for practical classes, extracurricular activities, curriculum, diagnostic tools, syllabus, exam tickets; for applicants for higher education degree "bachelor" full-time and part-time educational forms for the specialty 011 "Educational, pedagogical sciences". Kharkiv: Ukrainian Engineering Pedagogics Academy. 171 p. DOI: https://doi.org/10.5281/zenodo.4110899 [Ukrainian]

38. Poroshenko, M. A. (2019). Inclusive education: a textbook. Ukraine Agency LLC, Kyiv, Ukraine, 300. ISBN: 978-966-137120-9. [Ukrainian]

39. Matveeva, N. (2017). Inclusive education in Ukraine: social and pedagogical aspects. Educational space of Ukraine, 11, 180-187. DOI: https://doi.org/10.15330/esu.11.180-187 [Ukrainian]

40. Shevchenko, A. S., Gavrilov, E. V. (2020). Infectious safety issues in work instructions and educational disciplines of valeology and health pedagogy on the example of the current COVID-19 coronavirus pandemic. Proceedings of the II International Scientific and Technical Internet Conference "Latest Technologies in Education, Science and Production" (April 16, 2020). Ukraine, Pokrovsk: SHEl "DonNTU", 182-186. DOl: https://doi.org/10.5281/zenodo.3950555 [Russian].

41. Lysenko, O. (2017). Valuable attitude to health as a system-building component of value orientations of the personality. Educational space of Ukraine, 11, 144-154. DOI: https://doi.org/10.15330/esu.11.144-154 [Ukrainian]

42. Vasylyuk, V. M. (2021). Health-preserving competence is an important component of the professional competence of a modern teacher. Innovations in high school: development prospects. Collection of materials of the V International theoretical and practical conference "Innovations in high school: problems and prospects in education and science". PC KRHPA named after Taras Shevchenko, 5, 105-110. URL: https://is.gd/rey2la (accessed 20.09.2021). [Ukrainian]

43. Shtefan, L.V., Shevchenko, A.S. (2020). Relationship of ecological and valeological competence in the process of teaching the academic discipline "Health Pedagogy". Collection of materials of the scientific-practical conference of students, young scientists and doctors "Kharkiv International Annual Scientific Meeting" (KhIASM'20) (Ukraine, Kharkiv, KNMU, May 22, 2020), 35-36. DOI: https://doi.org/10.5281/zenodo.3856423

44. Shevchenko, V. V., Shevchenko, A. S., Shayda, V. P. (2019). Proposals for modernization fire safety systems of Ukrainian Nuclear Power Plants. Collection of Materials of the Ist International Scientific and Technical Internet Conference "Advanced Technologies in Education, Science and Industry" (ISBN 978-617-7761-45-6), Ukraine, Pokrovsk, April 18, 2019, Section 1 "Current problems and prospects for the development of industries related to energy, mechanization and automation", 76-80. DOl: https://doi.org/10.5281/zenodo.2622126 [Ukrainian]

45. Matus, S. A., Levina, G. M., Karpyuk, T. S., Denishchik, O. Yu. (2019). Analytical report "Basic study of the state and directions of development of environmental policy of Ukraine and prospects for strengthening the participation of civil society organizations in the development and implementation of environmentally friendly policies" (period: 2018 - January 2019), study commissioned by the International Renaissance Foundation. Kyiv. 117. URL: https://is.gd/6W9B8f (accessed 20.09.2021). [Ukrainian]

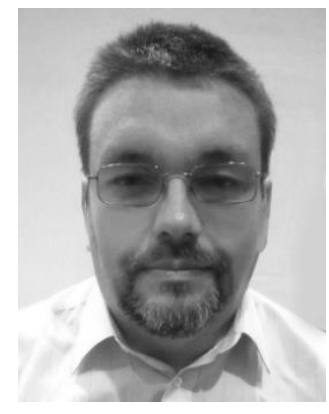

\section{Шевченко Олександр Сергійович.}

Лікар, магістр медицини, економіки та педагогіки, аспірант.

Українська інженерно-педагогічна академія.

вул. Університетська, 16, Харків, Україна, 61003.

Тел. +38 063069 9000. E-mail: al.shevchenko1976@gmail.com

Shevchenko Alexander Sergeevich.

Medical Doctor, Master of Medicine, Economics and Pedagogy, PhD Student.

Ukrainian Engineering Pedagogics Academy.

University str., 16, Kharkiv, Ukraine, 61003.

Phone: +38 063069 9000. E-mail: al.shevchenko1976@gmail.com

ORCID: https://orcid.org/0000-0002-4291-3882 


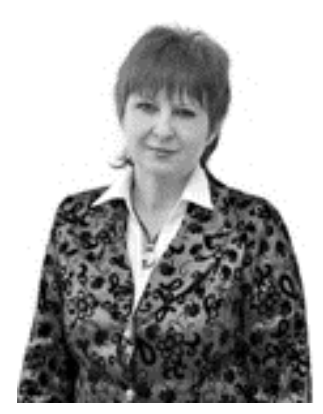

\section{Штефан Людмила Володимирівна.}

Доктор педагогічних наук, професор.

Професор кафедри Педагогіки, методики та менеджменту освіти.

Українська інженерно-педагогічна академія.

Поштова адреса: Україна, 61003, Харків, вул. Університетська, 16.

Тел. +38050 0268 668. E-mail: Ivlshtefan@gmail.com

\section{Shtefan Liudmyla Vladimirovna.}

Doctor of Pedagogical Sciences, Professor.

Professor of the Department of Pedagogy, Methods and Management of Education.

Ukrainian Engineering Pedagogics Academy.

Post Address: Ukraine, 61003, Kharkiv, University str., 16.

Phone: +38 0500268 668. E-mail: Ivlshtefan@gmail.com

ORCID: https://orcid.org/0000-0002-9910-5499

\section{Citation (APA):}

Shevchenko, A., Shtefan, L. (2021). Formation of valeological competence in non-medical students. Engineering and Educational Technologies, 9 (4), 8-23. doi: https://doi.org/10.30929/2307-9770.2021.09.04.01

\section{Цитування (ДСТУ 8302:2015):}

Шевченко О. С., Штефан Л. В. Формування валеологічної компетентності у студентів немедичного профілю навчання I Інженерні та освітні технології. 2021. Т. 9. № 4. С. 8-23. doi: https://doi.org/10.30929/2307-9770.2021.09.04.01

Обсяг статmі: $\quad$ сторінок - 16 ; умовних друк. аркушів - 2,318. 